\title{
A COMPARATIVE STUDY OF NUTRITIONAL PARAMETERS IN HEMODIALYSIS PATIENTS
}

\author{
( Received:15.10.2006 ) \\ By \\ A .A. Alshatwi \\ Food Science and Nutrition Department, College of Agriculture and Food Science, \\ King Saud University, Saudi Arabia
}

\begin{abstract}
The high prevalence of protein-energy malnutrition (PEM) is a critical issue for patients with end stage renal disease (ESRD) on hemodialysis (HD). The aim of this study was to compare the nutritional indices of hemodialysis patients (HP) with healthy male subjects (control group) of the same age. Mean body mass index $(\mathrm{BMI})$ was significantly low $(\mathrm{p}<0.001)$ in patients as compared with the control group ( $23 \pm 3.8 \mathrm{vs} 30.2 \pm 3.5 \mathrm{~kg} / \mathrm{m}^{2}$, respectively). Similarly, the patients had body weight lower than the control group. The analysis of food intake showed that the mean energy and protein intakes were significantly lower in HP than the healthy subjects. Notably all patients had energy below the recommended intake for HP $(30 \mathrm{kcal} / \mathrm{kg} / \mathrm{d})$, meanwhile, only $25 \%$ of the patients had the protein intake above $1.2 \mathrm{~g} / \mathrm{kg} / \mathrm{d}$. The total proteins and mean serum albumin levels were significantly low $(\mathrm{p}<0.001)$ in patients as compared with healthy subjects $(6.6 \pm 0.42 \mathrm{Vs} 7.5 \pm 0.3 \mathrm{~g} / \mathrm{dL}$ and $3.05 \pm 0.39 \mathrm{Vs} 4.5 \pm 0.35 \mathrm{~g} / \mathrm{dL}$, respectively). Moreover, $81.3 \%$ of the patients had serum albumin level less than $3.5 \mathrm{~g} / \mathrm{dl}$, and $59.4 \%$ of these patients had moderate deficit (serum albumin; $2.98-3.5 \mathrm{~g} / \mathrm{dL}$ ) while $21.9 \%$ of them had a severe deficit (serum albumin level of lower than $2.98 \mathrm{~g} / \mathrm{dL}$ ). Notably, none of the patients had serum albumin higher than 4.0 $\mathrm{g} / \mathrm{dL}$ in contrast, all healthy subjects (control) had serum albumin levels higher than $4.0 \mathrm{~g} / \mathrm{dL}$. In conclusion, the present results of this study suggest that malnutrition is common in HP in Saudi Arabia and HP is at high risk mortality and morbidity. It is important to take some responsible and effective steps to correct the malnutrition of HP. To improve health and nutrition status for HP, energy and protein, in addition to other nutrients supplementation are recommended.
\end{abstract}

Key words: end-stage renal diseases, hemodialysis, nutrition status, protein-energy malnutrition, serum albumin, serum creatinine.

\section{INTRODUCTION}

Malnutrition is present to some extent in approximately $40 \%$ of HP (Bergström and Lindholm 1993; Cuppari et al., 1994; Rezende et al., 2000). Moreover, the prevalence of PEM in patients with ESRD is reported to vary between $30 \%$ and $76 \%$ and PEM is associated with increased morbidity and mortality. Many markers of malnutrition, including low BMI and low serum albumin have been associated with high morbidity and mortality rates in this group of patients (Lowrie and Lew 1990; Rezende et al., 2000; Akner and Cederholm 2001; Shinaberger et al., 2006). There were several causes which may promote malnutrition, and few studies of multiple factors analysis about the nutrition of HP were discussed. The nutritional status of HP in Saudi Arabia has not been well established. Therefore, the objective of this study was to analyze some possible factors contributing to malnutrition, including protein and energy intakes, BMI, total protein, serum albumin, and serum creatinine, and to compare the nutritional indices of HP with healthy male subjects of the same age. This study may help to improve meals of the nutritional status of HP as a part of an ongoing prospective work.

\section{MATERIALS AND METHODS}

The study was carried out on 32 male patients with ESRD who had been undergoing maintenance hemodialysis and were considered to be clinically stable. Also total of 39 age-matched healthy male subjects (control group) were subjected to provide blood samples for serum 
albumin, total protein and other parameters for comparison with HD patients who were randomly chosen from Riyadh central Hospital in Riyadh City. Blood samples were drawn from the patients under fasting conditions immediately before the dialysis session for the determination of biochemical assays. Albumin, urea, and serum creatinine were determined with a standard autoanalyzer. The intakes of energy and protein were determined by 3-day food record. The energy and protein intakes were compared with American Dietetic Association (ADA) (2000) The energy and protein intake were calculated for ideal body weight (Kopple 1994; Lorenzo et al., 1995; Chertow and Lazarus 1997; Schmicker 1995; Toigo et al., 2000). The recommended energy intake is $35 \mathrm{kcal}$ per $\mathrm{kg}$ body weight for those who are younger than 60 years and 30-35 kcal per kg body weight per day for those who are 60 years or older. The recommended protein intake is 1.2-1.4 g/kg/day (ADA 2000). Postdialysis creatinine concentration prediction is well correlated with the urea reduction ratio (URR $=1-$ $\mathrm{R}$ where $\mathrm{R}=\mathrm{Urea}_{\text {post }} / \mathrm{Urea}_{\text {pre. }}$ Post-dialysis). Creatinine was calculated according to the following formulas; $\mathrm{Cr}_{\text {post }}=\mathrm{Cr}_{\text {pre }} \mathrm{X}(1-0.857 \mathrm{X}$ URR) - 28 (Desmeules et al., 2004). The cutoff low albumin was set at $<3.5 \mathrm{~g} / \mathrm{dL}$ (Health Care Financing Administration. 1998; Pichard et al., 2004). Serum albumin levels ranged $2.98-3.5$ $\mathrm{g} / \mathrm{dL}$ have been considered moderate deficit and serum albumin levels $<2.98 \mathrm{~g} / \mathrm{dL}$ have been considered severe deficit (Rogen, et al., 1988). The statistical analysis included means; standard deviations, were analyzed by SSPS version 10 .

\section{RESULTS}

Characteristics of the subjects are presented in (Table 1) and showed that the mean BMI was significantly low $(\mathrm{p}<0.001)$ in HD patients as compared with the control group ( $23 \pm 3.8$ vs 30.2 $\pm 3.5 \mathrm{~kg} / \mathrm{m}^{2}$, respectively). Similarly, the patients had body weight significantly lower than the control group $(p<0.001)$. The analysis of food intake showed that the mean energy and protein intakes were significantly higher in the healthy subjects than HP $\quad(\mathrm{p}<0.001$ and $\mathrm{p}<0.05$, respectively) (Table 2 ). The mean energy and protein of patients were $20.9 \pm 6.2 \mathrm{kcal} / \mathrm{kg} / \mathrm{d}$ and $0.85 \pm 0.3 \mathrm{~g} / \mathrm{kg} / \mathrm{d}$, respectively, whereas, the mean energy and protein were $28.9 \pm 4.4 \mathrm{kcal}$ $/ \mathrm{kg} / \mathrm{d}$ and $1.1 \pm 0.3 \mathrm{~g} / \mathrm{kg} / \mathrm{d}$. for healthy subjects, respectively (Table 2). Notably all patients had energy below the recommended intake for HP (30
Table (1): Characteristics of the study population ( mean \pm S.D.).

\begin{tabular}{|l|l|l|l|}
\hline Parameter & patients & control & p \\
\hline Number & $\mathbf{3 2}$ & $\mathbf{3 9}$ & \\
\hline Age $($ year $)$ & $\mathbf{5 1 . 5} \pm \mathbf{3 2}$. & $\mathbf{5 3} \pm \mathbf{1 0 . 2}$ & $\mathbf{0 . 0 8}$ \\
\hline Height $(\mathbf{c m})$ & $\mathbf{1 6 6} \pm \mathbf{1 0 . 4}$ & $\mathbf{1 6 8 . 4} \pm \mathbf{6 . 5}$ & $\mathbf{0 . 0 9}$ \\
\hline Wight $(\mathbf{k g})$ & $\mathbf{6 3 . 5 . 1} \pm 15.3$ & $\mathbf{8 5 . 7 6} \pm \mathbf{1 2 . 5}$ & $<\mathbf{0 . 0 0 1}$ \\
\hline IBW $(\mathbf{k g})$ & $\mathbf{6 6} \pm \mathbf{8 . 4}$ & $\mathbf{6 8} \pm \mathbf{8 . 4}$ & $\mathbf{0 . 1}$ \\
\hline BMI $\left(\mathbf{k g} / \mathbf{m}^{2}\right)$ & $\mathbf{2 3} \pm \mathbf{3 . 8}$ & $\mathbf{3 0 . 2} \pm \mathbf{3 . 5}$. & $<\mathbf{0 . 0 0 1}$ \\
\hline
\end{tabular}

Table (2): Intakes of energy and protein.

\begin{tabular}{|l|l|l|l|}
\hline & Patients $(\mathrm{n}=32)$ & Control $(\mathrm{n}=39)$ & P \\
\hline Energy $(\mathrm{kcal} / \mathrm{kg} / \mathrm{d})$ & $\mathbf{2 0 . 9} \pm \mathbf{6 . 2}$ & $\mathbf{2 8 . 9} \pm \mathbf{4 . 4}$. & $<\mathbf{0 . 0 0 1}$ \\
\hline Protein $(\mathrm{g} / \mathrm{kg} / \mathrm{d})$ & $\mathbf{0 . 8 5} \pm \mathbf{0 . 3}$ & $\mathbf{1 . 1} \pm \mathbf{0 . 3}$ & $<\mathbf{0 . 0 5}$ \\
\hline
\end{tabular}

$\mathrm{kcal} / \mathrm{kg} / \mathrm{d}$ ) meanwhile only $25 \%$ of patients had protein intake above $1.2 \mathrm{~g} / \mathrm{kg} / \mathrm{d}$. The total proteins and mean serum albumin concentrations were significantly low $(\mathrm{p}<0.001)$ in patients as compared with healthy subjects $(6.6 \pm 0.42$ vs 7.5 $\pm 0.3 \mathrm{~g} / \mathrm{dL}$ and $3.05 \pm 0.39$ vs $4.5 \pm 0.35 \mathrm{~g} / \mathrm{dL}$, respectively) (Table 3 ). The mean serum albumin level in patients was $3.05 \pm 0.39 \mathrm{~g} / \mathrm{dL}$ which was substantially lower than the normal range. Moreover, $81.3 \%$ of the patients had serum

Table (3): Total protein and serum albumin in study groups (mean \pm S.D.).

\begin{tabular}{|c|c|c|c|}
\hline Parameter & $\begin{array}{l}\text { Patients } \\
(n=32)\end{array}$ & $\begin{array}{l}\text { Control } \\
(n=39)\end{array}$ & $\mathbf{P}$ \\
\hline Total protein (g/dL) & $6.6 \pm 0.42$ & $7.5 \pm 0.3$ & $<0.001$ \\
\hline Albumin (g/dL) & $3.05 \pm 0.39$ & $4.5 \pm 0.35$ & $<0.001$ \\
\hline URR (\%) & $68 \pm 13.2$ & & \\
\hline Urea: $\mathbf{C r}$ & $12: 1$ & & \\
\hline
\end{tabular}

albumin level less than $3.5 \mathrm{~g} / \mathrm{dL}$, and $59.4 \%$ of these patients had moderate deficit (serum albumin; 2.98-3.5 g/dL) while $21.9 \%$ of them had severe deficit (serum albumin level lower than $2.98 \mathrm{~g} / \mathrm{dL}$ ) (Table 4). In contrast, only $18.7 \%$ had serum albumin higher than $3.5 \mathrm{~g} / \mathrm{dL}$. Notably, no one of the patients had serum albumin higher than $4.0 \mathrm{~g} / \mathrm{dL}$, while the mean serum albumin level for healthy subjects was $4.5 \pm 0.35 \mathrm{~g} / \mathrm{dL}$. Moreover, all the healthy subjects (control) had a serum albumin levels higher than $4.0 \mathrm{~g} / \mathrm{dL}$. In the control samples, the average urea concentration was $38.3 \pm 8.3 \mathrm{mg} / \mathrm{dL}$, which was markedly less than that of pre-HD $(75.6 \pm 16.6 \mathrm{mg} / \mathrm{dL})$, and higher than post-HD $(25.5 \pm 8.1) \quad$ (Fig. 1). The average creatinine concentration was $0.79 \pm 0.19 \mathrm{mg} / \mathrm{dL}$ which was markedly less than that of pre-HD (7.5 $\pm 1.9 \mathrm{mg} / \mathrm{dL})$, and post-HD $(3 \pm 1.1 \mathrm{mg} / \mathrm{dL})$ (Fig.2). Both urea and creatinine levels were significantly higher in the patients on dialysis compared with the control samples $(p<0.001)$. 
Table (4): Percentage of patients with moderate and severe deficient.

\begin{tabular}{|c|c|c|c|c|c|c|}
\hline & \multicolumn{3}{|c|}{ Patients (32) } & \multicolumn{3}{|c|}{ Control (39) } \\
\hline & $\begin{array}{l}\text { Mean } \pm \text { SD } \\
\text { range }\end{array}$ & $\begin{array}{l}\text { Moderate } \\
\text { Deficit }\end{array}$ & $\begin{array}{l}\text { Severe } \\
\text { Deficit }\end{array}$ & $\begin{array}{l}\text { Mean } \pm \text { SD } \\
\text { range }\end{array}$ & $\begin{array}{l}\text { Moderate } \\
\text { Deficit }\end{array}$ & $\begin{array}{l}\text { Severe } \\
\text { Deficit }\end{array}$ \\
\hline Albumin & $3.05 \pm 0.39$ & $59.4 \%$ & $21.9 \%$ & $4.5 \pm 0.35$ & $0 \%$ & $0 \%$ \\
\hline (g/dL) & 2.34-3.87 & & & 4.01-5.69 & & \\
\hline
\end{tabular}

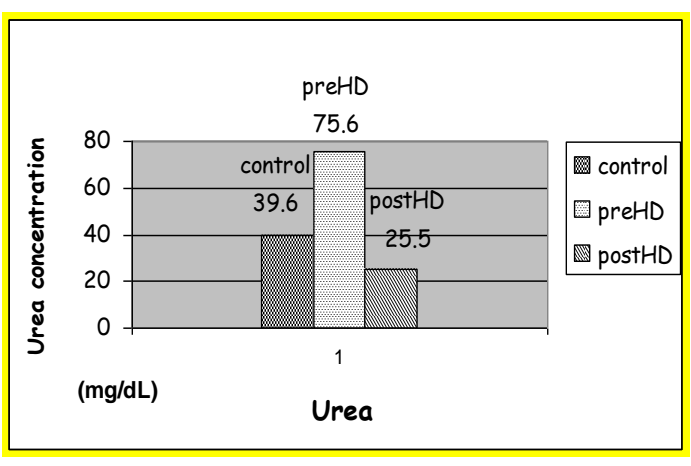

*Significant mean differences between pre-HD and normal control, between post-HD and normal control $(p<0.001)$.

Fig. (1): Urea in normal control, pre-HD and postHD Patients

\section{DISCUSSION}

Malnutrition is an important predictor of mortality in ESRD population. Serum creatinine and albumin can be measured easily and have been observed to be independent predictors of death (Lowrie et al., 1995; Faintuch et al., 2006). Daily protein intake is primary devoted to the preservation of muscle mass and body nitrogen reserves. For this reason, creatinine-based indices should be strongly used among the parameters to evaluate PEM. The serum creatinine concentration is related to nutritional status in that it reflects somatic protein stores, muscle mass, and intake of dietary protein. Mortality risk is associated with low serum creatinine levels in HP. In any case, low serum creatinine concentrations have been observed to be highly predictive of future mortality in HP (Lowrie and Lew 1990; Owen and Lowrie 1998; Pifer et al., 2002). This was confirmed by Pifer's study who also found that mortality risk was inversely associated with baseline serum creatinine level and decreased in the serum creatinine concentration. Mortality risk was 60 to $70 \%$ higher in the lowest quartile group as compared with the highest quartile group (Pifer et al., 2002). In this study, the mean serum creatinine concentration for the patients, 7.6 $\mathrm{mg} / \mathrm{dL}$, was lower than Pifer's result. In the present study, serum creatinine levels were also low when compared with other studies (Allman,

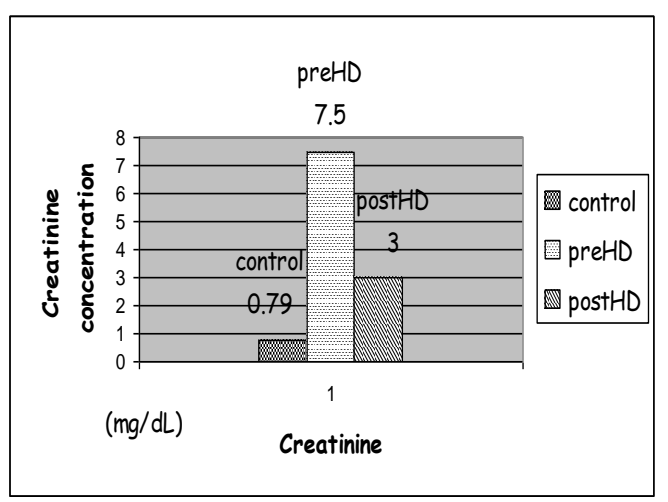

*Significant mean differences between pre-HD and normal control, between post-HD and normal control $(p<0.001)$

Fig. (2): Creatinine in normal control, pre-HD and post- HD Patients.

Iqbal et al., 2005). In contrast, the mean serum creatinine concentration for healthy subjects was within the normal range $(0.7-1.2 \mathrm{mg} / \mathrm{dL})$. Although there is no reference value for serum creatinine for HP, the serum creatinine in the present study was low. Therefore, the HP are more likely represent to be at risk of death.

A low serum albumin level is a strong predictive risk factor. Since it is a marker of visceral protein stores (Kaysen et al., 1997, Dutton et al., 1999; Leon et al., (2006). In this study the total proteins and mean serum albumin concentrations were significant low in patients group compared with healthy subjects $(p<0.001)$. The mean serum albumin level for patients was $3.05 \pm 0.39 \mathrm{~g} / \mathrm{dL}$ which was substantially lesser than normal range. (Table 3 ). In England and USA, Huidobro et al., (2001) and Kimmel et al., (2003), observed that the mean serum albumin was lower than $4.0 \mathrm{~g} / \mathrm{dL}$. Recently Morsch et al., 2005 found that the mean serum albumin was $3.6 \mathrm{~g} / \mathrm{dL}$. Owen et al., 1994 found that the serum albumin level was a more powerful (21 times greater) predictor of death than the URR, and $60 \%$ of the patients had serum albumin concentrations predictive of an increased risk of death (serum albumin level below $4.0 \mathrm{~g} / \mathrm{dL}$ ). Importantly, $81.3 \%$ of the patients had a serum albumin level less than 3.5 
$\mathrm{g} / \mathrm{dL}$, and $59.4 \%$ of these patients had moderate deficit (serum albumin; 2.98-3.5 g/dL) while $21.9 \%$ of them had a severe deficit (serum albumin level of lower than $2.98 \mathrm{~g} / \mathrm{dL}$ ) (Table 4). Notably, none of the patients had serum albumin higher than $4.0 \mathrm{~g} / \mathrm{dL}$. In contrast, the mean serum albumin level for healthy subjects was $4.5 \pm 0.35 \mathrm{~g} / \mathrm{dL}$. Moreover, all healthy subjects (control) had serum albumin levels higher than $4.0 \mathrm{~g} / \mathrm{dl}$. Low total protein and low serum albumin levels observed in this study may largely be attributed to the low intake of protein (75\% of the patients had protein intake below $1.2 \mathrm{~g} / \mathrm{kg} / \mathrm{d}$.). Although, protein needs for HP $(1.2-1.4 \mathrm{~g} / / \mathrm{kg} /$ day) are high compared with recommended requirements for the general population $(0.8 \mathrm{~g} / / \mathrm{kg} / \mathrm{day})$, the mean intake of dietary protein for HP was $0.85 \pm 0.4 \mathrm{~g} / \mathrm{kg} /$ day (Table 2) . This was significantly $(\mathrm{p}<05)$ lower than the control group $(1.1 \mathrm{~g} / / \mathrm{kg} /$ day $)$ and substantially less then the recommended intake for HP $(1.2 \mathrm{~g} / \mathrm{kg} / \mathrm{d}$.). In addition, energy deficiency might be an important factor to poor utilization of dietary protein. Energy intake should be sufficient to prevent catabolism and achieve and maintain optimal nutrition status. Adequate energy from carbohydrates and fats may prevent muscle and visceral protein from being used as energy sources (Beto 1995; Heathcock et al., 1996; Turner et al., 1997; ADA 2000). However, all patients in this study had energy below the recommended intake for HP (30 kcal $/ \mathrm{kg} / \mathrm{d})$ with an overall sample mean of mean energy $20 \mathrm{kcal} / \mathrm{kg}^{\prime}$ day. Moreover, the mean energy intake was significant lower $(\mathrm{p}<0.001)$ than the control group (28.9 $\mathrm{kcal} / \mathrm{kg}^{\prime}$ day) and was far below the recommended requirements for HP (30-35 $\mathrm{kcal} / \mathrm{kg}^{\prime}$ day (Table 2). Valenzuela et al., 2003 found that $74 \%$ of HP in France had energy intake less than the recommended requirements, whereas $86 \%$ and $70 \%$ of HP in Spain and Italy, respectively, had energy intake less than the recommended requirements (Lorenzo et al., 1995; Bossola et al., 2005). The latter observed that $70.2 \%$ of HP had a protein intakes less than $1.0 \mathrm{~g} / \mathrm{kg} /$ day whereas $37.8 \%$ and $47 \%$ of HP in China and Brazil, respectively, had a protein intakes less than the recommended requirements (Ge et al., 1998; Valenzuela et al., 2003). HP have critically low levels of protein, energy (Table 2) and other nutrients including calcium, phosphorus, iron, vitamin $\mathrm{B}_{12}$, vitamin $\mathrm{B}_{6}$ and folate (data not shown). Reduced dietary protein intake may be associated with elevated mortality risk in individuals with ESRD undergoing maintenance hemodialysis (MHD) (Shinaberger et al., 2006). Furthermore, the hemodialysis procedure may cause low total and serum albumin either by inducing losses of amino acids and other nutrients or by promoting inflammatory responses through bloodmembrane interactions (Gutierrez, et al., 1990). HP have significant alterations in their intracellular and plasma amino acid profile, which has been attributed to a low protein diet or insufficient intake, impaired protein or amino acid catabolism, and long-term dialysis. Loss of amino acid during dialysis has evidently been shown (Bergstrom et al., 1990; Ikizler et al., 1995; Navarro et al., 2000). There are many possible reasons for PEM in HP. The most important cause of inadequate energy, protein and other nutrients intake is almost certainly anorexia. Anorexia may be caused by several factors including uremic toxins, gastrointestinal disorder and psychosocial disorder (Bergstrom, 1995; Laville and Fouque 2000). It has been demonstrated that uremia alters appetite (Ikizler et al., 1995; Johansen et al., 1998). Zinc deficiency contributes to taste disturbances (Laville and Fouque 2000).

Urea is the major metabolic end product of amino groups derived from amino acids. The plasma concentrations of most amino acids in HP with ESRD were increased due to increased protein catabolism. The accumulation of amino acids resulted in more waste products, including urea and ammonia, potentially contributing to greater morbidity in these patients. HD are effective in reducing some of the accumulated amino acids, hence restoring the plasma amino acid levels toward normal (Chuang et al., 2006). Urea reduction ratio is defined as the percent reduction in blood urea nitrogen concentration during a single dialysis treatment. The risk of death was determined as a function of the urea reduction ratio and serum albumin concentration. Owen et al., (1994) found that patient with URR below 60 percent had a higher risk of death during follow-up (odds ratio, 1.28 for urea reduction ratios of 55 to 59 percent and 1.39 for ratios below 55 percent). Fifty-five percent of the patients had urea reduction ratios below 60 percent. Low urea reduction ratios during dialysis are associated with increased odd ratios for death.

These risks are worsened by inadequate nutrition (Owen et al., 1994). In this study, 19 
$\%$ of the patients had urea reduction ratios below 60 percent. Therefore, HP are at risk of death and the risks are worsened by malnutrition or inadequate nutrition observed in this study.

In conclusion, the data in this study suggest that malnutrition is common in HP in Saudi Arabia and $\mathrm{HP}$ are at high risk mortality and morbidity. It seems important to take some responsible and effective steps to correct the malnutrition of HP. To improve health and nutrition status for HP, energy and protein supplementation are recommended.

\section{REFERENCES}

Akner G. and Cederholm T. (2001). Treatment of protein-energy malnutrition in chronic nonmalignant disorders. Am. J . Clin Nutr.: 74(1):6-24.

Allman M. A., Stewart P.M., Tiller D.J, Horvath J.S, Duggin G.G and Truswell S. (1995). Energy supplementation and the nutritional status of hemodialysis patients. Am. J Clin. Nutr; 51:358-362

American Dietetic Association (2000). Manual of Clinical Dietetics. $6^{\text {th }}$ Ed. American Dietetic Association. Chicago, 1ll. USA.

Bergstrom J. (1995). Why are dialysis patients malnourished. Am. J. Kidney Dis;26(1): 22941. Review.

Bergstrom J., Alvestrand A. and Furst P (1990). Plasma and muscle free amino acids in maintenance hemodialysis patients without protein malnutrition, Kidney Int. 38 (1): 108 114.

Bergström J and Lindholm B (1993). Nutrition and adequacy of dialysis: How do hemodialysis and CAPD compare Kidney International, 43 (Suppl 40): 39-50.

Beto J. (1995). Which diet for which renal failure: making sense of the options J. Am. Diet Assoc.: 95:898-903.

Bossola M., Muscaritoli M., Tazza L., Panocchia N., Liberatori M., Giungi S., Tortotelli, Fanelli F.R., and Luciani G. (2005). Variables associated with reduced dietary intake in hemodialysis patients. J. Ren Nutr. 15 (2):244252.

Chertow G.M and Lazarus J.M (1997). Malnutrition as a risk factor for morbidity and mortality in maintenance dialysis patients. In: Kopple J. D and Klahr S .G., Editors, Nutritional Management of Renal Disease, Williams and Wilkins, Baltimore, p. 257-276.

Chuang C., Lin S., Chen H., Chen Y., Wang T., Wen-Hsiang Shieh W. and Wu C.J. (2006). Plasma free amino acids and their metabolites in Taiwanese patients on hemodialysis. and continuous ambulatory peritoneal dialysis. Clinica Chimica Acta, 364 (1-2) :209-216.

Cuppari L., Medeiros F.A.M. Pappini H.F. Cendorolo Neto M., Canziani M.E.F., Martini L, Ajzen $\mathrm{H}$ and Draibe S.A. (1994). Effectiveness of oral energy-protein supplementation in severely malnourished hemodialysis patients. Journal of Renal Nutrition, 4 (Suppl 3): 127-135.

Desmeules S., Lévesque R., Jaussent I., LerayMoragues H., Chalabi L. and Canaud B. (2004). Creatinine index and lean body mass are excellent predictors of long-term survival in haemodiafiltration patients. Nephrol. Dial. Transplant 19: 1182-1189 .

Dutton J., Campbell H., Tanner J., and Richards N. (1999). Pre-dialysis serum albumin is a poor indicator of nutritional status in stable chronic haemodialysis patients. EDTNA ERCA J.;25(1):36-37.

Faintuch J., Morais A.A., Silva M.A., Vidigal E.J., Costa R.A., Lyrio D.C., Trindade C.R. and Karoline K.P. (2006). Nutritional profile and inflammatory status of hemodialysis patients. Ren. Fail.;28 (4) : 295-301.

Fujino Y., Ishimura E., Okuno S., Tsuboniwa N., Maekawa K., Izumotani T., Yamakawa T., Inaba M. and Nishizawa Y (2005). C-reactive protein is a significant predictor of decrease in fat mass in hemodialysis patients Biomed Pharmacother; 59(5):264-268.

Ge Y.Q., Wu Z.L., Xu Y.Z., and Liao L.T. (1998). Study on nutritional status of maintenance hemodialysis patients. Clin Nephrol. Nov: 50(5): 309-314.

Gutierrez A., Alvestrand A., Wahren J. and Bergstrom J. (1990) Effect of in vivo contact between blood and dialysis membranes on protein catabolism in humans. Kidney International, 38: 487-494.

Health Care Financing Administration. (1998). Annual report ESRD Core Indicators Project. Available from: URL: http:I|www.hcfa.gov. qualityl3h.htm.Accessed 28 November 1999.

Heathcock P., Nabel J., Norton P., Heile S., and Royse D. (1996). An exploration of the relationship between nutritional status and quality of life in chronic hemodialysis patients. J. Renal. Nutr: 6: 152-7

Huidobro A., Velasco N., and Rojas T. (2001). Prevalence of calorie protein malnutrition among patients in chronic hemodialysis. Rev. Med. Chil; 129 (5): 495-502.

Ikizler T.A., Greene J., Wingard R.T., Parker P.A. and Hakin R.M. (1995). Spontaneous 
dietary protein intake during progression of chronic renal failure. Journal of the American Society of Nephrology, 6: 13861391.

Iqbal M.M., Islam M.N., Mansur M.A., Naeem G.M, Sattar H., Hossain R.M., Mohsin M., Rahman M.H., Rashid H.U. (2005). Outcome of peritoneal dialysis and hemodialysis in elderly patients with diabetes: early experience from Bangladesh Adv. Perit. Dial; 21:85-89.

Johansen K.L., Mulligan K., Tai V. and Schambelan M. (1998). Leptin, body composition, and indices of malnutrition in patients on dialysis. J. Am. Soc. Nephrol.;9(6):1080-1084.

Kaysen G.A., Stevenson F.T and Depner T.A (1997). Determinants of albumin concentration in hemodialysis patients. Am. J. Kidney Dis.; 29(5):658-668.

Kimmel P.L., Emont S.L., Newmann J.M., Danko H. and Moss A.H.(2003). ESRD patient quality of life: symptoms, spiritual beliefs, psychosocial factors, and ethnicity. Am Kidney Dis.; 42(4): 713-721.

Kopple J.D. (1994). Effect of nutrition on morbidity and mortality in maintenance dialysis patients. Am. .J Kidney Dis.; 24: 1002-1009.

Laville M. and Fouque D. (2000). Nutritional aspects in hemodialysis. Kidney Int. Suppl., 76: S133-139.

Leon J.B., Albert J.M., Gilchrist G., Kushner I., Lerner E., Mach S., Majerle A., Porter D., Ricanati E., Sperry L., Sullivan C., Zimmerer J., and Sehgal A.R. (2006). Improving albumin levels among hemodialysis patients: a community-based randomized controlled trial. Am. J. Kidney Dis.; 48(1):171-173.

Lorenzo V., DeBonis E. and Rufino M. (1995) Caloric rather than protein deficiency predominates in stable chronic haemodialysis patients. Nephrol Dial Transplant 10:18851889.

Lowrie E.G., and Lew N.L. (1990). Death risk in hemodialysis patients: the predictive value of commonly measured variables and an evaluation of death rate differences between facilities. Am. J. Kidney Dis.; 15(5):458-482.

Lowrie E.G., Huang W.H. and Lew N.L. (1995) .Death risk predictors among peritoneal dialysis and hemodialysis patients: a preliminary comparison. Am J Kidney Dis; 26: 220-228.

Morsch C., Goncalves LF and Barros E. (2005) End stage renal disease severity index, clinical indicators and mortality of hemodialysis patients. Rev. Assoc. Med. Bras.: 51(5):296300.

Navarro J.F., Mora C., Leon C., Martin-Del Rio R., Macia M.L., Gallego E., Chahin J., Mendez MLRivero A, and Garcia J. (2000) Amino acid losses during hemodialysis with polyacrylonitrile membranes: effect of intradialytic amino acid supplementation on plasma amino acid concentrations and nutritional variables in nondiabetic patients, Am. J. Clin Nutr. 71 . (3), : 765-773.

Owen W.F. and Lowrie E.G. (1998). C-reactive protein as an outcome predictor for maintenance hemodialysis patients.Kidney Int.;54(2):627-636.

Owen W.F. Jr., Lew N.L., Liu Y., Lowrie E.G. and Lazarus J.M. (1994). The urea reduction ratio and serum albumin concentration as predictors of mortality in patients undergoing hemodialysis. Engl J Med. 24; 330 (8) : 573574.

Pichard C., Kyle U.G., Morabia A., Perrier A., Vermeulen B. and Unger P. (2004). Nutritional assessment: lean body mass depletion at hospital admission is associated with an increased length of stay. Am J Clin Nutr; 79(4) :613-618.

Pifer T.B., McCullough K.P., Port F.K., Goodkin D.A., Maroni B.J., Held P.J. and Young E.W. (2002). Mortality risk in hemodialysis patients and changes in nutritional indicators: DOPPS. Kidney Int. :62 (6) : 2238-2245.

Rezende L.T.T, Cuppari L., Carvalho A.B, Canziani M.E.F., Manfredi S.R., Cendoroglo M., Sigulem D.M. and Draibe S.A. (2000): Nutritional status of hemodialysis patients with secondary hyperparathyroidism. Braz $\mathbf{J}$ Med. Biol. Res, 33: (11) 1305-1311.

Rogen M., Hull A., and Davis M. (1988). Eds. Nutrition support of the renal patients. Zeman F.J.(1991) Clinical; nutrition and dieteics.2ed. p.318

Schmicker R. (1995). Nutritional treatment of hemodialysis and peritoneal dialysis patients. Artif Organs 19: 837-841.

Shinaberger C.S., Kilpatrick R.D., Regidor D.L., McAllister C.J., Greenland S., Kopple J.D. and Kalantar-Zadeh K. (2006). Longitudinal associations between dietary protein intake and survival in hemodialysis patients. Am. J. Kidney Dis ; 48(1):37-49.

Stenvinkel P., Barany P., Chung P.H., Lindholm B. and Heimburger O. (2002) .A comparative analysis of nutritional parameters as predictors of outcome in male and female ESRD patients. Nephrol Dial Transplant,17: 1266-1274. 
Toigo G., Aparicio M., Attaman P.O., Cano N, Cianciaruso B., Engel B., Fouque D., Heidland A., Teplan V. and Wanner C. (2000). Expert working group report on nutrition in adult patients with renal insuffciency (Part 2 of 2).Clinical Nutrition19 (4) p 281-291.

Turner L.W., Faile P., Wang M.Q and Fu Q., (1997). Dietary management in the patients with chronic renal failure. Am. J. Nephrol.; 97:16B$16 \mathrm{H}$.
Valenzuela RG, Giffoni AG, Cuppari L and Canziani ME.(2003). Nutritinal condition in chronic renal failure patients treated by hemodialysis in Amazonas. Rev Assoc Med Bra; 49(1):72-108.

Vendrely B, Chauveau P, Barthe N, Haggan WE, Castaing F, Precigout VD, Combe C and Aparicio M. (2003) Nutrition in hemodialysis patients previously on a supplemented very low. protein diet. Kidney International, 63: 1491-1498.

\author{
دراسة تغذوية مقارنة لمرضي الغسيل الكلوي الدموي \\ علي عبداللـه الثتوي
}

قسم علوم الأغذية والتغذية ـ كلية علوم الأغذية والزراعة ـ جامعة الملك سعود ـ الرياض- المملكة العربية السعودية

ملخص

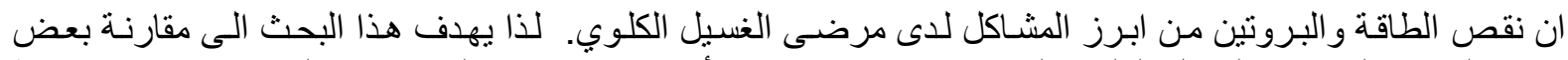

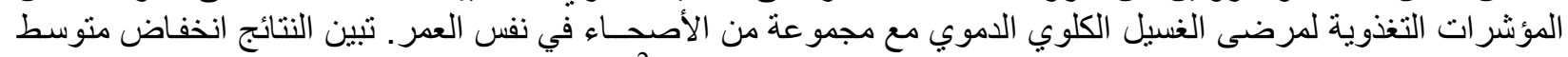

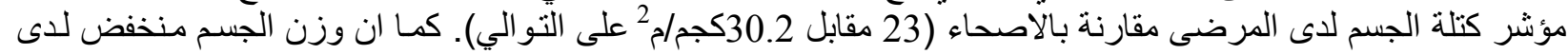

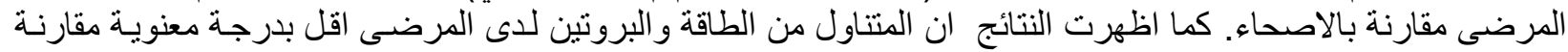

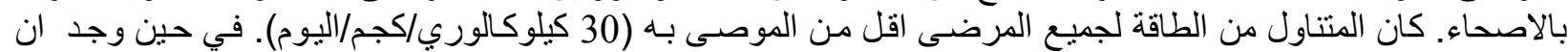

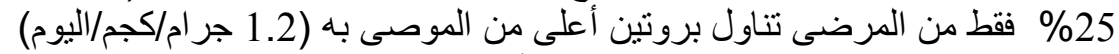

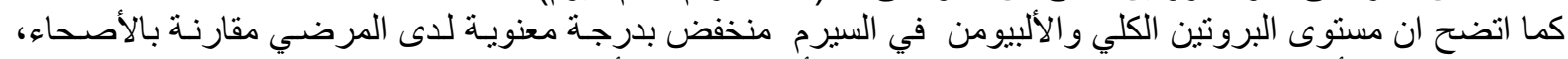

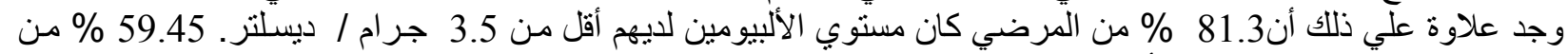

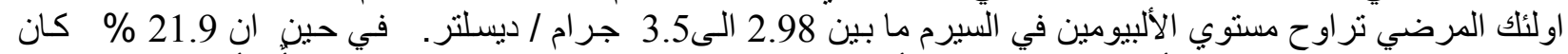

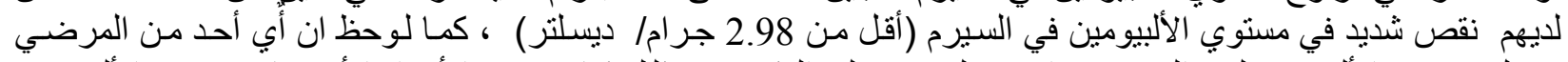

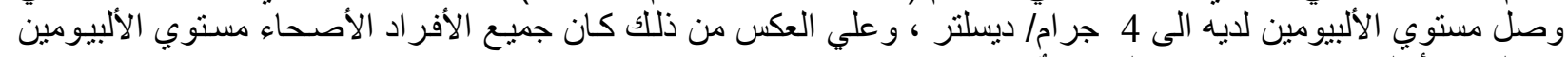

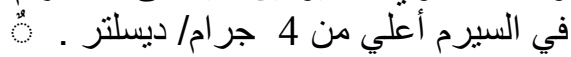

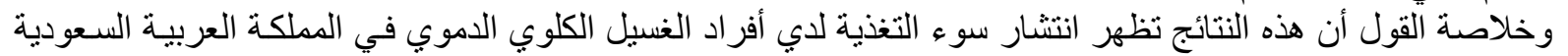

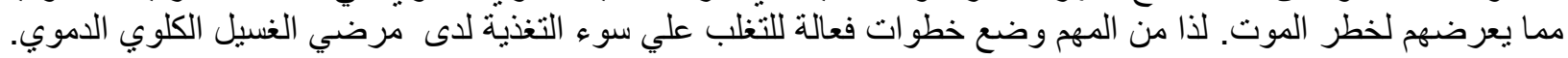

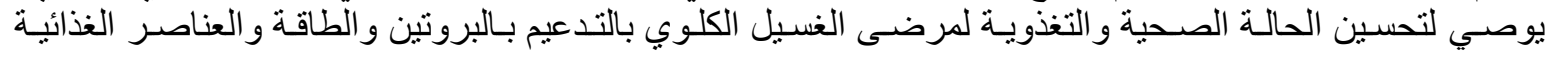

الأخرى.

المجلة العلمية لكلية الزراعة - جامعة القاهرة - المجلد (58) العدد الثاني ( أبريل 2007 ):105-111. 